\title{
A Study on Professional Career Improvement of Air Force Firefighters Through Education and Training
}

\author{
이주환* · 황의홍** · 최돈묵*** \\ Lee, Joohwan*, Hwang, Euyhong ${ }^{* *}$, and Choi, Donmook ${ }^{* * *}$
}

\begin{abstract}
Military air bases accommodate large-scale ammunition storage facilities that can potentially cause huge damage to human life and property. Therefore, the Air Force fire department in a military airfield is required to effectively educate and train firefighters based on the Air Force fire safety manual not only to prevent fire proliferation, but also to rescue pilots and people from aircrafts and military facilities. However, it was found that there are several factors that impede the professional career improvement of the fire department. These factors include theory-dependent fire education training methods, lack of fire drill procedures, shortage of safety instructors, and limitations of fire expert training. This study proposes several potential solutions to elevate the knowledge and skills of the Air Force firefighters for effective fire prevention and rescue operations by restructuring the practical education and training systems through case analysis and comparison.
\end{abstract}

Key words : Air Fore Fire Protection, Career Certificate, Air Force Fire Education Training

\section{요 지}

공군 비행장은 대형화재의 잠재성을 지닌 시설 등으로 인해, 화재 발생 시 위험성이 크다. 이에 따라 공군 소방대는 모든 사고에 대해 화재 진압 및 구조 지원을 위한 가용 재원과 체계적인 계획안을 마련하여 이를 교육 - 훈련해야 한다. 하지만 다양한 문제점으로 인해 소방교관의 교육 업무량이 증가하여 직무 교육의 전문성을 저해하는 결과로 이어지고 있다. 따라서 현재 시행되고 있는 교육·훈련의 문제점과 공군에서 소방직무를 수행하는 인원의 전문성과 실전능력을 확보하기 위한 교육체계의 개선 방안을 제시하고자 한다. 본 연구에서는 국내·외 소방 기관의 교육 및 훈련 체계에 관한 사례들을 비교 분석한 뒤, 국내 공군 소방직무 전문성 제고를 위한 개선 방안을 도출하였다.

핵심용어 : 공군 소방, 전문자격 인증, 공군 소방 교육·훈련

\section{1. 연구배경 및 목적}

공군 비행장의 소방대는 대형화재 예방활동 및 화재방지 대응능력 뿐만 아니라 항공기 비상상황 발생 시 조종사 등 생존 가능한 인명 구조 능력을 갖춰야 한다.

실무부대의 소방진압과 항공작전 지원에 필요한 전문성 과 실전능력을 확보한 전문인을 배양하기 위해서는 공군
교육부대의 교육 - 훈련을 강화하는 것이 필요하다.

공군 교육부대의 소방교육 - 훈련은 전문성과 실전능력 을 높이기 위해 '17년 실제소방훈련장을 구축하여 이론 위주 의 교육에서 실습 위주의 교육체계로 체질을 개선하였음에 도 불구하고 교육 운영차수의 증가, 전문소방 인력 양성 미흡, 시설물 안전요원 등의 부재 등 문제점이 나타났다. 문제점은 소방교관의 업무량과 직접적으로 관련이 있다.

*정회원, 가천대학교 산업환경대학원 설비소방공학과 석사과정(E-mail: Joohwan70@naver.com)

Member, Master Candidate, Fire \& Disaster Protection Engineering, Graduate School of Industry \& Environment, Gachon University

**정회원, 가천대학교 설비소방공학과 석사과정

Member, Master Candidate, Fire Protection Engineering, Gachon University

***교신저자, 정회원, 가천대학교 설비소방공학과 교수(Tel: +82-31-750-5716, Fax: +82-31-750-8749, E-mail: fire@gachon.ac.kr)

Corresponding Author, Member, Professor, Fire \& Disater Protection Engineering, Gachon University 
업무량이 증가하면 교육운영 집중력 저하와 실무부대 화재 현장의 소방 초동조치를 위한 팀원 간의 신속한 의사결정, 효과적인 상황판단 역량저하에 영향을 준다.

본 연구에서는 군 공항에서 소방업무를 담당하는 소방요 원을 대상으로 공군에 입대하여 소방업무를 접하는 공군 교육부대 소방 교육·훈련인 특기교육의 현 실태를 파악하 였다. 다양한 형태의 대형화재와 항공기 사고구조 등 상황처 리의 전문성을 향상시키기 위한 방법에 대해 국내·외 문헌 과 연구자료, 논문을 검토하였다. 군 비행장의 소방력 향상을 위한 교육·훈련 전문성 제고 방안에 대하여 분석하여 최적 의 소방교육 및 훈련체계 개선방안을 제시하고자 한다.

\section{2. 공군 소방교육 및 훈련 운영체계}

\section{1 비행장 소방업무 운영체계}

공군은 전쟁을 수행하기 위한 핵심 전력으로서 어떠한 상황이 발생하더라도 최상의 항공작전이 원활히 유지될 수 있도록 지원하고 임무수행이나 비행훈련 중 불가피하게 발생할 수 있는 위험상황에 대비해야 한다. 따라서 화재진압 과 인명구조에서 한 치의 오차 없이 정확히 수행하고, 신속하 게 처리할 수 있어야 한다.

공군 소방대는 항공기 비상상황과 군사시설물의 화재출 동에 있어서 활주로 등 출동이 용이하도록 시야가 확보되어 야 한다. 이 상태에서 각 활주로 끝까지 3 분 이내에 출동할 수 있는 지역에 위치하여 항공기 사고 및 군사시설물의 재난상황에서 신속-정확하게 인명구조, 화재진압, 군내 자산인 공항 시설물을 보호 등을 해야 한다.

또한 소방요원의 기량향상에 필요한 항공기 화재진압 및 인명구조 훈련과 군·관 합동소방훈련 등 훈련 요구량을 설정하여 주기적으로 실시하며 유류저장지역 및 탄약저장 시설 등 재난사고에 대비하기 위해 인근 소방관서와 긴밀한 상호협조체계를 구축하고 군 - 관 합동소방훈련을 연 2회 이상 시행하여 대형재난 대응절차를 수립하여 대비한다.

또한 항공기 소방구조를 위한 항공기의 접근과 취급 시설 물의 위험을 숙지할 부분은 교육- 훈련을 통해 전문성을 향상시키고 있다.

\section{2 항공기 화재진압 및 인명구조 훈련}

공군 비행장에서 운영하는 항공기 기종과 크기에 따른 화재진압 대응과 구조절차 등 기량을 향상하기 위해 매 분기마다 항공기 사고구조 종합훈련을 실시하여 위급상황 에서 긴급 대처가 가능하도록 능력을 확보하고 있다.

항공기 화재진압 훈련은 항공기의 예기치 않은 결함에 의하여 활주로에 불시착하는 것을 가정하여 훈련이 진행되 며 항공기의 무장장착 상황과 파손 정도에 따라 항공기 화재진압과 조종사의 인명구조의 우선순위를 설정하여 훈 련을 하게 된다.
가상의 항공기가 활주로에 접근하기 전 조종사로부터 긴급한 비상상황 조치를 통보받으면 공항의 관제탑은 관련 부서에 1차로 상황전파를 통보하게 된다. 비상상황을 통보 받은 관련부서는 활주로 대기선에 신속하게 출동하여 긴급 상황에 대비하고 항공기가 착륙 후 화재상황이 전개되면 소방요원은 소방차량을 화재현장으로 신속하게 접근하여 화재를 진압하게 된다.

화재 항공기에 접근 전에 관제탑으로부터 소방차에 탑재 된 무선통신장비를 통해 항공기의 결함내용과 무장 장착 상태 등을 사전에 파악할 수 있다.

현장에 출동한 항공기 화재진압용 차량은 항공기의 위치, 항공기 형태, 적재폼, 화재발생과 풍속과 풍향, 구조요원의 진입로를 고려하여 차량을 위치시키고 항공기의 화점을 향해 소방차량의 포탑을 이용하여 다량의 폼(Form)을 살포 한다.

화재진압 시 폼(Form) 살포는 상황별 화재진압 방법에 따라 가능한 기체에 근접한 위치에서 실시하고 기체의 선을 따라 방출한 후 불이 밖으로 밀려나도록 하며 조종사 주변을 중심으로 소화 작업을 진행하여 초도 불길을 잡는다.

이후 구조요원들은 사다리를 전개하여 캐노피의 개방과 연료차단 등의 임무를 수행하며 위급상황의 조종사를 구조 하여 응급요원에게 인계한 뒤 화염에 휩싸인 항공기 화재를 진압한다.

항공기 화재진압 훈련은 소방요원의 화재진압의 기량을 항상하기 위해 월 1 회 이상 실시하고 있으며 항공기의 기종과 크기에 따라 절차를 수립하여 화재진압과 인명구조를 실시 한다.

항공기 비상출동 절차와 조종사 구조 및 화재진압, 항공기 에 접근 시 위험요소에 대한 교육·훈련은 위급한 상황 시 소방요원의 경험에 도움을 준다.

\section{3 군사시설물 화재진압 훈련}

재난현장에서 소방요원의 화재진압 대응능력은 소방의 가장 기본적인 업무 중의 하나로 각종 화재 및 재난으로부터 안전과 생명을 보호해야 할 의무가 있다.

최근에는 건축재료 종류의 다양성과 건축자재의 사용의 증가로 건물화재 시 다량의 연기와 열기가 발생되어 사람들 에게 생존의 위협을 초래하게 되어 화재진압 기술의 고도화 가 필수적이다. 따라서 성공적인 화재진압활동을 위해선 다양한 환경에 대한 전문적인 진압 장비와 기술, 전문인력 양성을 위한 교육-훈련이 중요성을 지적했다(Cho, 2013).

군사시설의 주요시설물인 격납고는 주기적인 화재진압 훈련을 실시해야 한다. 격납고 내 항공기는 대체적으로 연료 가 비워져 정비에 관한 일련의 과정을 진행하지만 방호, 강화 격납고(PASS)의 항공기는 대부분 연료가 가득 채워져 있으며 미사일 등 각종 무장과 탄약을 장착하고 있다.

이것은 화재를 동반한 급격한 폭발의 가능성이 있어 매우 
위험함을 알 수 있는데 특히 연료가 가득 채워진 경우 항공기 화재 시 다량의 검은 연기가 생성되어 상승하면서 다량의 열기류가 형성 할 수 있으므로 화재발생 시 공군 소방대를 활용하여 초기 화재 진압으로 대응하여야 한다(Ryu, 2017).

이와 같이 화재진압을 안전하고 효과적으로 수행하기 위해서는 화재의 진행 단계별로 미치는 영향에 대해 교육훈련을 통한 기본적인 이해가 필요하다.

주요시설물인 격납고, 대량 탄약저장시설 및 유류저장지 역 등은 화재발생 시 초기 화재진화에 실패할 경우 연쇄적인 재난으로 발전할 수 있는 상황이 발생하므로 대형 재난사고 에 대비하여 인근 소방관서와 긴밀한 상호협조체계도 유지 하고 있다.

\section{4 교육부대 교육과정}

공군에 입대하면 군인으로서 기본자질을 갖추고 전투임 무수행을 담당할 수 있도록 기본군사훈련을 통해 양성되는 데, 군사훈련 기간 동안에는 군인복무 기본법, 군법, 전쟁법 등에 관한 이론교육과 유격훈련, 행군, 총검술 등 육체적 단련을 통해 군인으로 강인한 정신력과 체력을 겸비하게 되면 전공과 관련된 특기를 부여받아 특기교육을 이수하게 된다.

Table 1 과 같이 소방분야 특기교육 초급과정의 자격조건 은 기본군사교육을 이수하고 특기 부사관/병으로 임관한 자에 한하여 교육을 받을 수 있다. 세부 교육 내용으로서 소방관계법령, 화재대응능력 항공기 소방구조, 소방시설 유지관리, 화재진압전술, 소방설비의 운영 등으로 구성되어 있다.

또한 실무부대에서 업무를 수행하는 간부 대상의 보수교 육은 부사관 중급, 고급으로 실시하고 있으며 한 계급 승급을 위한 자격조건을 갖춰야하는 필수과정이다. 항공소방 보수 과정은 실무부대에서 다 년간의 업무를 수행해온 반장에 준하는 직급으로서 실제 현장에서 항공기 사고구조와 화재 진압을 실시한 요원을 대상으로 교육을 실시하여 직무수행
에 필요한 제반 직무지식과 기술 습득 향상을 위해 교육을 실시한다.

\section{3. 국내·외 소방 교육·훈련 체계}

\section{1 국내 소방 교육·훈련체계}

\subsection{1 공항공사}

항공기 사고는 하나의 작은 실수로 인해 막대한 인명손실 은 물론 대형의 재난사고이기에 항공법, 공항안전기준 (Airport Operations Standards), 공항구조 및 소방에 관한 안전운영기준, 국제 민간 항공협약서 등을 참고하여 구조. 소방 업무 체계를 갖추고 항공 사고 발생 시 비상체계를 세워야함을 의무화하고 있다(MOLIT, 2013a).

국내 공항공사는 실제화재 훈련장(항공소방훈련장)을 설 치하여 항공기 화재에 적합한 훈련을 실시하고 있으며 인천 국제공항과 김포국제공항 내에 항공기 모형 실제 화재진압 훈련을 실시하고 있다.

실제화재훈련의 목적은 소방구조요원이 실제 항공기 화 재(화염)에 접할 수 있는 기회를 제공하여 화재성향 경험을 습득하고, 유사시 긴급한 상황에 효과적인 화재진압 능력을 배양하는 훈련으로 소방 구조요원이 항공기 화재의 유형에 따른 적합한 소화제의 사용과 화재진압 전술의 경험을 통해 개인능력을 배양할 기회를 제공한다.

훈련현황은 항공기 사고 수습훈련과 소방훈련으로 구성 하고 사고발생시 단계별(10분/30분/1시간/2시간)로 구성하 여 대응 조치 및 절차 숙지와 상황전파, 화재진압 및 인명구조 등 초동조치 대응능력 향상과 다양한 형태의 사고 훈련을 실시하고 있다.

Fig. 1과 같이 소방훈련은 실제로 소방 구조 요원이 항공기 화재를 직접 접할 수 있도록 공항안전운영기준(AOS)에 의 한 연료화재를 포함하여 매 12 개월마다 최소 1 회 이상의 실제 화재 훈련에 참가하고 있다.

Table 1. Curriculum of Air Force Fire Education and Training

\begin{tabular}{|c|c|c|c|c|}
\hline \multicolumn{2}{|c|}{ Track and level } & \multicolumn{2}{|c|}{ Duration } & Curriculum \\
\hline \multirow{5}{*}{$\begin{array}{l}\text { Initial Training } \\
\text { track }\end{array}$} & \multirow{2}{*}{$\begin{array}{l}\text { Air Force Fire } \\
\text { Protection: entry level }\end{array}$} & Basic training & 6-week & Basic military training, etc. \\
\hline & & $\begin{array}{l}\text { Professional } \\
\text { training }\end{array}$ & 3-week & $\begin{array}{l}\text { Basic fire protection and fire suppression } \\
\text { techniques, etc. }\end{array}$ \\
\hline & \multirow{3}{*}{$\begin{array}{c}\text { Air Force Fire } \\
\text { Protection: officer } \\
\text { entry level }\end{array}$} & Basic training & 11-week & Basic military training, etc. \\
\hline & & \multirow{2}{*}{$\begin{array}{l}\text { Professional } \\
\text { training }\end{array}$} & \multirow{2}{*}{ 11-week } & $\begin{array}{l}\text { Fire regulations, Fire protection management, } \\
\text { rescue operations, etc. }\end{array}$ \\
\hline & & & & $\begin{array}{l}\text { Aircraft fire rescue operations, Fire facility } \\
\text { management, fire maintenance, etc. }\end{array}$ \\
\hline \multirow{2}{*}{$\begin{array}{l}\text { Maintenance } \\
\text { track }\end{array}$} & \multirow{2}{*}{$\begin{array}{c}\text { Air Force Fire } \\
\text { Protection: officer } \\
\text { entry level }\end{array}$} & Intermediate & 3-week & $\begin{array}{l}\text { Fire facility management, Fire suppression } \\
\text { techniques and discussion, etc. }\end{array}$ \\
\hline & & Advanced & 3-week & $\begin{array}{l}\text { Fire suppression strategy, Fire facility } \\
\text { management, Field investigations, etc. }\end{array}$ \\
\hline
\end{tabular}




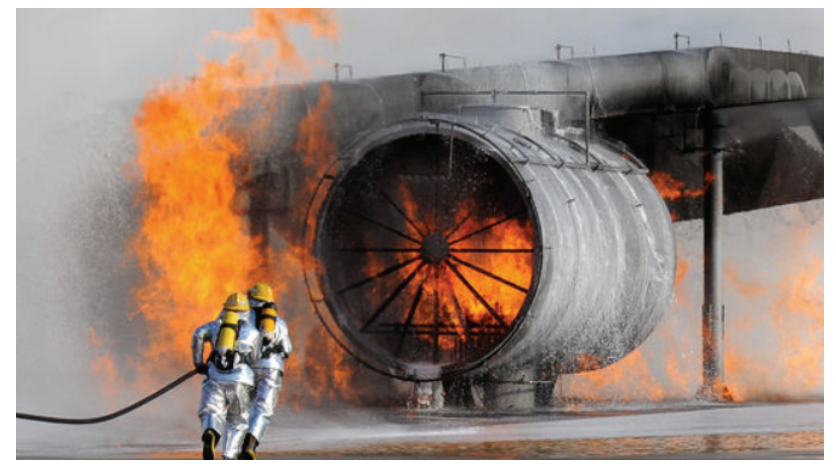

Fig. 1. Image of Aircraft Fire Suppression Techniques (Source: Google)

또한 항공기 사고에 대비한 화재진압 훈련과 공항내의 시설물과 지형을 파악하기 위한 공항 숙지 훈련, 항공기 기종에 따라 항공기 내부의 비상문의 위치, 밧데리 등 위치를 파악 등을 실시하고 있다.

\subsection{2 중앙 소방학교}

중앙 소방학교(National Fire Service Academy)는 재난 현장에서 강한 인재 양성을 목표로 소방 고급간부의 리더십 과 화재 및 재난상황에서의 위기관리 능력을 배양하기 위한 현장지휘역량 강화에 중점을 두고 있다. 또한 전문소방관 배양을 위한 화재대응능력과 응급구조사, 인명구조사, 화재 조사관 등 직무에 관련된 전문자격 교육훈련 등을 중점적인 과제로 설정하여 운영하고 있다.

교육훈련은 소방업무의 특성을 고려하여 화재 · 구조· 구급 등의 현장 활동에서의 필요한 지식과 능력을 습득시키 기 위한 신임교육, 초동대응 현장지휘관으로서의 판단력과 상황지휘 능력 등 관리역량 강화를 목적으로 한다.

이를 위해 지휘역량교육, 방호조사(방-실화, 발화개소 판정, 전기·화학 - 가스- 폭발), 화재대응(화재 시 화재진 압의 위험요소를 파악한 뒤, 개인 안전확보 및 효율적인 화재 진압법으로 현장대응), 인명구조(재난상황 대비 인명 구조 및 응급처치 등), 특수재난(화생방 테러대응, 지진붕괴 대응, 유해화학물 사고 대응)등 대처하는 전문교육 중심으 로 교육·훈련을 실시하고 있다.

\subsection{3 국내 해외연수 교육·훈련 체계}

경기도 소방학교의 신임 소방공무원 교육·훈련체계 혁 신 방안에서 소개된 텍사스 $\mathrm{A} \& \mathrm{M}$ 대학 소방훈련 기관의 리쿠루트 아카데미 과정(Recruit Firefighter Academy)은 국 내 소방전문교관을 양성하고 교육-훈련 체계를 정비하며 양질의 소방 교육 프로그램 개발을 목표로 하는 선진 소방교 육·훈련 연수 프로그램이다.

이 연수 프로그램은 경기도 소방학교에서 소방 우수교원 양성을 위해 국내 처음으로 시행된 것으로서 화재진압, 구조 및 위험물에 대한 이론 실습형태의 12 주간 소방 교육- 훈련
이다.

기초체력훈련(1 2주차)을 시작으로 사다리 관련 이론 실 습(3주차), 소방 호스 이론 실습(4주차), 소방 차량 개론(5주 차), 소방차 조작 및 작동실습(6주차), 강제 배연 및 장제 진입(7주차), 차량 구출 및 로프구조(8주차), 위험물 식별 및 대응(9주차), 실제화재 진압훈련(11 12주차)에 이르기까 지 모든 과정은 연방소방학교(National Fire Academy, NFA) 의 교제를 중심으로 운영된다(Im, 2006).

특히 신임 소방관 대상 텍사스 A\&M 대학 리크루트 연수 과정 참가자의 만족도는 일반 교육 - 훈련과정 (52.3\%) 대비 $87.4 \%$ 로서, 소방 교육·훈련 측면에서 매우 긍정적으로 평가되었다. 전문 교관 및 교육요원에 대한 만족도 역시 일반 교육·훈련과정 (56.7\%) 대비 텍사스 A\&M 대학 리크 루트 연수과정 참가자의 만족도가 $85.7 \%$ 로 압도적이었으 며, 이는 소방교육 전문 인력의 중요성을 다시 한 번 부각 시키는 대목이다. 이러한 관점에서 소방-교육훈련의 직무 능력을 향상을 위한 해외 연수프로그램은 우수한 자원이 투입된 소방 교육기회를 활용하여 해외의 선진화된 소방기 술을 배울 수 있는 좋은 기회로 활용하고 있다.

\section{2 국외(미국) 소방 교육・훈련체계}

\subsection{1 미국 연방소방학교(NFA)}

미국 연방소방학교는 2011년부터 “소방 고등교육 직무 개발 위원회(The Fire and Emergency Services Higher Education Professional Development Committees)"를 통하 여 현장출동, 화재예방, 소방행정, 구급행정 등에 관한 기준 을 마련하였으며 많은 대학이 미 연방 소방학교의 기준에 따라 학과 내용을 적용하고 미 연방 소방학교로부터 심사를 통해 인증을 받게 되면 인증 받은 교육기관을 졸업한 사람들 에 대해서는 전국적으로 동일한 수준의 지식과 업무능력을 수행할 수 있게 된다.

미국 연방소방학교의 소방 교육·훈련은 철저한 이론 및 실습위주의 훈련을 통해 실제 상황에서 소방진압 및 구조 확률을 높일 수 있도록 운영하여 화재진압 및 인명구조 능력 향상을 극대화 시키고 있으며 자연재난 및 사회재난에 대비하기 위해 체계적인 조직을 바탕으로 전문부서, 전문교 관, 훈련시설과 장비를 갖추고 재난을 극복하고 더 나아가 세계적으로 기술을 전파하고 있다.

미국의 각 기관들은 미국 연방소방학교와 미국방화협회 의 기준에 맞는 커리큘럼을 마련하여 소방대의 자격을 엄격 하게 제한하고 있으며 교육 시스템의 기준에 부합되는지는 인증기관으로부터 인증을 받아 소방관계자 직급 및 직무별 매뉴얼을 통해 효과적으로 달성하고 있다.

\section{2 .2 미 국방부 종합소방학교}

미 국방부 종합소방학교(DoD Fire Academy)는 육 - 해 · 
공군, 해병대, 해안경비대 소속의 미군과 민간인 소방대원을 양성하는 소방학교로 교육·훈련체계는 교육현장에서 다양 한 프로그램의 소방직무에 관한 교육을 기초적인 화재진압 및 소화이론부터 항공기 사고구조 훈련과 항공기 내부화재, 엔진화재 등 화재진압과 사고·구조 교육을 받게 된다.

Table 2. Curriculum of the U.S. National Fire Academy

\begin{tabular}{c|l}
\hline Category & \multicolumn{1}{c}{ Curriculum } \\
\hline \multirow{2}{*}{ Block I } & $\begin{array}{l}\text { - Fire Protection Fundamental } \\
\text { • Structural Firefighting Principles }\end{array}$ \\
\hline \multirow{2}{*}{ Block II } & - Structural Fire Ground perations \\
\hline \multirow{3}{*}{ BlockIII } & - Hazardous Materials \\
\cline { 2 - 2 } & - Airport Firefighter \\
\cline { 2 - 2 } & - Emergency Medical Responder \\
\hline
\end{tabular}

Table 2와 같이 소방 전문교육은 Block I (화재성상 및 예방), Block $\Pi$ (건물화재 이론, 화재진압 실습), BlockII(위 험물, 항공기 화재진압, 응급구조)으로 구분하여 다양한 실 습장과 이동식 트레일러들도 갖춰져 교육이 진행되며 교육 을 이수한 소방대원에게는 화재 대응능력(Fir Figher I / II), 위험물(HAZMAT Awareness/Operations), 구급(Emergency Medical Responder) 분야의 수료증이 수여된다(Lee, 2016).

또한 미 공군은 직급별 인증 요건에 따라 소방경력은 특정 기술수준 및 직무와 관련된 미 국방부(The US Department of Defense)의 인증 요구사항을 충족시켜야 한다. 일정 자격 을 갖춘 소방관은 Table 3 과 같이 해당 수준에서 미 국방성의 평가를 받아야하며 등급 유지에 필요한 최소한 등급을 인증 요건으로 이수하여야 한다(Lee, 2014).

Table 3. Required Career Certificates by the Level of the U.S. Firefighter

\begin{tabular}{|c|c|}
\hline Level & Required career certificate \\
\hline $\begin{array}{l}\text { Apprentice } \\
\text { firefighter }\end{array}$ & $\begin{array}{l}\text { - Firefighter I and II } \\
\text { - Hazardous Materials Awareness } \\
\text { - Airport Firefighter } \\
\text { - Emergency Medical Responder }\end{array}$ \\
\hline Journeyman & $\begin{array}{l}\text { - Driver Operator Pumper } \\
\text { - Driver Operator ARFF } \\
\text { - Driver Operator Mobile Water Supply }\end{array}$ \\
\hline Craftsman & $\begin{array}{l}\text { - Fire Officer I } \\
\text { - Fire Instructor I } \\
\text { - Fire Inspector I } \\
\text { - Hazardous Materials echnician Munitions } \\
\text { Firefighting }\end{array}$ \\
\hline Superintendent & $\begin{array}{l}\text { - Fire Officer IV } \\
\text { - Fire Inspector II } \\
\text { - Fire Instructor II } \\
\text { - Hazardous Materials Incident Commander } \\
\text { - Incident Safety Officer } \\
\text { - ICS } 300 / 400\end{array}$ \\
\hline
\end{tabular}

\section{4. 문제점}

\section{1 공군 소방요원 전문자격 검증의 한계}

소방공무원 전문화 방안 및 전문자격 인증제도에 관한 연구에 따르면 재난현장에서 활동하는 소방공무원의 전문 성을 높이기 위해 신임 소방공무원의 개별 업무수행에 요구 되는 전문자격을 수여하는 소방관 전문자격 제도의 도입을 제시했다.

현장에서 활동하는 소방공무원의 전문성을 강화하기 위해 구급분야에 시행해오던 전문자격 인증시스템을 화재 진압 분야와 인명구조 자격인증 제도를 확대하여 화재대 응능력, 인명구조사, 응급구조사, 화재조사관 등 화재, 구 조, 구급의 3 대 현장업무의 전문자격 인증 체계를 갖추게 되었다.

반면, 국내 공군 비행장의 소방요원은 다양한 재난·재해 의 현장에 대비하기 위해 항공기 사고구조 및 건물화재 진압훈련을 월 1 회 이상, 유류화재훈련은 매 분기 1 회 및 민 - 관 합동소방훈련을 통해 실전적인 대처능력 향상에 대비하고 있다.

다양한 재난현장에서 항공기 구조업무를 포함한 화재진 압 및 인명구조 등 실시하고 있으나 공군 소방업무에서 요구되는 기술을 화재현장과 인명구조의 현장에서 필요한 지식을 인지하고 있는지 명확하게 입증할 수 있는 직무요구 사항의 기준이 필요하다.

\section{2 공군 교육부대 소방 전문교관 확보 한계}

국내 소방학교는 교육·훈련의 질적 향상과 효과를 극대 화하기 위하여 소방 관련 분야의 전문성과 경험을 가진 전문교관 및 연구요원 양성에 투자를 확대해 오고 있다. 교육생 대상 강의, 소방교육훈련 프로그램 개발, 교과목 설계 지원, 효율적인 교수법 개발, 토론식 수업지도 연구논 문 발표 등 다양한 전문적인 업무를 추진하고 있다. 산 - 학 연 협력단체와의 유대관계를 강화하고 다양한 정보와 전문 지식 교육을 통한 소방분야 교육·훈련 역량강화를 도모하 고 있다.

현재 공군 소방교육운영은 부사관 초급, 중급, 고급, 항공 병 차수와 기타 육군 소방병 등을 교관 3 명에 조교 1명으로 연간 교육차수를 운영하고 있다. 적은 교관인원으로 많은 교육생들을 교육하다보니 화재상황을 부여한 화재진압 전 술, 대형 유류화재 대처방법, 항공기 화재진압 교육 등에 대한 개인별 실습의 기회가 부족한 상황이 반복되고 있는 실정이며 전공과목의 연구 기회가 부족하여 교과목에 대한 내실 있고 충실한 교육이 되기 어렵다.

또한 교관의 평균 근무기간이 3년 정도로 짧아 교육의 전문성 확보에 요구되는 근무기간이 부족하여 소방교육의 이론과 실습에 질적 수준을 항상하기 어려운 실정으로 교육· 훈련의 수준이 하향될 가능성이 있다. 


\section{3 공군 소방지휘역량 교육의 한계}

재난현장 지휘관 의사결정 역량 강화방안에 관한 연구에 따르면, 다양한 화재현장에서 필요한 역량으로서 상황판단 력(40\%), 의사결정력 $(24 \%)$ 이 전체 역량 중 $64 \%$ 를 차지하였 으며 다음으로 자원관리능력( $15 \%)$, 기타 5 가지 항목 $(21 \%)$ 순으로 나타났다. 또한 재난현장에서 지휘관의 의사결정을 방해하는 요인으로 외부의 압력, 전문적인 지식, 경험의 부족, 인력의 부족, 장비의 부족, 현장정보의 부족의 항목을 도출하여 Analytic Hierarchy Process (AHP, 계층적 분석절 차) 분석결과로 외부압력 $(25 \%)$, 전문지식 부족 $(21 \%)$ 순으 로 의사결정에 방해가 되는 가장 큰 요인으로 나타났다. 이러한 외부압력과 간섭이 현장지휘관의 의사결정을 방해 하여 소방대원의 목숨까지 위태롭게 하는 것으로 나타났다

(Seong, 2013).

현재 공군 교육부대의 소방교육은 직무와 관련된 교과목, 진급 위주의 교육으로만 진행되고 있다.

각 과정별로 소방직무 및 현장활동와 관련된 내용 교육하 고 있으나 광범위하고 이론 위주의 과정이여서 적절하게 직무역량이 확보 되었다고 판단하기 어렵다. 또한 보수교육 도 실시하고 있으나 이는 진급에 점수를 반영하기 위한 과정교육을 하고 있는 실정이라 소방요원의 의사결정능력 이나 지휘역량강화에 큰 도움을 주지 못하고 있다.

\section{4 훈련 시설 부족으로 전문적인 교육-훈련 한계}

공항안전운영기준(국토교통부 제2017-400호) 제147조에 따른 구조 및 소방의 교육훈련 내용은 임무수행에 적합하도 록 연료화재를 포함하여 매 12 개월 마다 최소한 1회 이상의 실제 화재훈련에 참가하도록 명시되어있다(MOLIT, 2013b).

미 공군 규정(AIR FORCE INSTURCTION) 32-2001의 훈련 프로그램 인증체계로 항공기 화재진압 실제훈련은 매년 최소 2 회 이상 실시하도록 명시하여 소방요원의 화재진 압 및 인명구조 능력을 향상시켜 화재진압 전술을 극대화 시키고 있다.

그러나 군 소방의 경우, 다수의 항공기 기종별 화재진압 훈련과 건물 화재진압 훈련을 통해 화재대응능력을 숙달하 고 있으나 소방요원이 실제화재를 접하여 훈련할 수 있는 훈련장이 조성되어있지 않아 가상의 화재를 설정한 화재진 압훈련은 소방요원의 화재진압 전술능력을 배양하는데 제 약이 따를 수 있다.

\section{5. 개선방안}

\section{1 공군 소방요원 전문자격 인증제도 개발}

소방관 전문자격 인증제도는 소방업무에 종사하는 소방 공무원들이 개별 업무 수행에 요구되는 전문자격을 취득하 는 것이다. 업무수행에 요구되는 지식과 능력은 국제적인
표준 기준으로 측정 및 평가하여 검증받는 것으로 서울 소방본부는 기본반과 자격반으로 구분하여 이론 및 실습교 육을 실시한 후 자격시험을 실시하고 있다.

이는 미국 연방소방학교의 자격인증과 같이 이론과 실습 위주의 훈련 후 분야별 시험을 통해 전문자격자를 양성하는 방식인데, 전문자격 소지자는 분야별 담당 업무를 수행하고 계급별 전문자격 취득자에게 승진 및 인센티브를 제공하는 방안이다.

하지만 이 방안 역시 한국 실정에 맞는 전문화된 세부기준 을 마련하여 분야별, 계급별 특성에 맞는 자격기준과 평가항 목을 개발하는 것이 필요하다.

현재 공군에서는 직무역량 강화를 위해 소방업무와 연계 성이 있는 소방설비(전기/기계), 위험물 관련, 안전관리 등 자격증에 한하여 가점을 부여하고 있으나 이는 실질적인 화재현장에서 소방구조, 화재진압에는 미비한 부분이 있어 소방 전문자격 조건의 범위를 확대하여 업무 수행에 요구되 는 전문자격 취득을 확대할 필요가 있다.

소방공무원의 전문자격(화재진화사, 인명구조사 등)은 국방부가 협약을 추진하여 공군 비행장의 소방 운영이 원활 하게 할 수 있도록 관계부처와 긴밀한 업무협약이 요구된다.

\section{2 해외 연수 및 훈련 참가자 등 우수인력 확보}

국내 소방학교 경우 교수요원들의 자질과 능력 향상을 위한 다양한 방법들이 동원되고 있다. 교육 프로그램 체계 개선을 위해 미국 등 선진 외국의 직무 연수를 실시하고 다양한 학술활동 지원을 통해 전문성을 확보해 나가고 있다.

공군 교육부대의 소방교관은 직무와 관련된 분야에서 5 년 이상 근무한 경력을 지닌 간부로 소방학교에 인사 보직되면 일정한 교육기간 동안 교관의 자질 심사를 통해 강의 능력을 평가받고 자체적으로 교관능력 향상을 위해 교수 연구 발표나 교관 중간평가 등을 통해 검증을 받고 있다.

공군의 직무능력 향상을 위한 해외연수 프로그램은 우수 한 선진 자원이 투입된 교육기회를 활용하여 해외의 선진화 된 소방기술을 배울 수 있는 좋은 기회로서 활용할 수 있다.

공군 교육부대는 소방교육과 연계한 교육·훈련 프로그 램에 적용할 수 있도록 교관선발 시 자격조건을 실무경력 5 년 이상, 교육점수 우수자 이외에 추가적으로 해외연수 교육 및 해외훈련 이수자에 대한 인센티브를 적용하고 선발 될 수 있도록 하여 소방교육의 다변화를 이끌어 낼 수 있을 것이다.

\section{3 공군 소방 지휘역량 교육 확대}

현장 지휘관은 화재, 재난·재해 그 밖의 위급한 현장에서 직관적이고 연속적인 의사결정을 내려 상황에 대응하는 
방향을 결정하므로 공군 교육부대는 소방 지휘관의 의사결 정능력을 향상시키기 위한 교육을 실시하여 한다. 간부대상 교육과정에 지휘역량 강화를 위한 교과목을 추가하거나 또는 보수과정을 신설하여 급박하고 다양한 유형의 현장에 서 발생한 의사결정을 통해 소방 초동지휘관의 의사결정 능력을 향상시킬 수 있다.

중간 간부를 대상으로 한 지휘능력 교육과정은 현장대응 에서 전문적인 지식과 문제해결 능력을 가지고 팀원간의 지시와 의사소통이 가능하도록 직급별 교육과정 커리큘럼 을 개발하여 재난상황의 특수성을 파악하고 정확한 의사결 정을 통한 정확한 행동이 이루어지도록 해야 한다.

보수교육(중급/고급)은 현장활동과 관련된 교과목으로 편성하여 화재 및 재난상황에서 초동조치를 위한 소방팀원 간의 의사결정 능력과 재난현장에서 문제점 등을 분석한 내용 발표를 통해 해결방안을 도출할 수 있으며 시뮬레이션 실습을 통해 공군 비행장의 대형화재 예상 지역인 무장 탄약고, 대형 유류저장탱크, 격납고 및 작전시설 등 특성화된 군내 시설물에 가상 상황을 부여하여 다양한 상황에서 대처 할 수 있는 능력을 배양하여 의사결정 능력 향상에 기여할 수 있다.

\section{4 외부 전문기관 협력 및 위탁교육 확대}

공항안전운영기준(국토교통부) 제 147 조에 따른 구조 및 소방 교육- 훈련으로 매 12 개월 마다 최소 1회 실화재훈련에 참가하도록 명시하였으며 인천국제공항, 김포국제공항 내 의 실제 화재훈련장을 활용하여 화재진압 능력을 극대화 시키고 있다.

공군 실무부대에서도 국제 민간항공기구(ICAO)와 국토 교통부 공항안전운영 기준에 따라 인천국제공항, 한국공항 공사와 소방훈련 $\mathrm{MOU}$ 를 체결하여 실제 모의항공기 화재진 압을 실시하고 한국 내 주둔한 미 공군 기지의 모의 항공기 실제화재 훈련장을 활용하여 한 - 미 공동 교육-훈련을 활성화하는 등 공군 소방대원과 실제 모의 항공기 합동훈련 을 주기적으로 진행하여 화재진압과 인명구조 등 초동조치 능력 강화를 할 수 있다.

또한 인근지역의 소방학교와 교육훈련 업무 협약을 체결하 여 공군 실무부대 소방요원이 소방학교의 전문교육 과정에 참여하여 소방학교 시설물 실 화재진압에 대한 교육·훈련의 지식과 기술을 습득하여 실전능력을 강화해야만 위급한 화재 및 재난상황에서 효과적으로 대처할 수 있는 능력을 발휘할 수 있다.

\section{6. 결 론}

공군 소방직무 전문성 향상위해 공군 교육부대 교육·훈 련을 통한 전문지식과 기술은 실무부대의 소방 활동에 필수 적인 사항이다.
이를 위해 소방조직의 교육·훈련 운영의 지속적인 개선 이 필요하며 이를 위해서 소방 업무 전문성 강화, 소방 직급별 커리큘럼 개발, 소방 교육 및 훈련시설 확충, 유능한 소방교관 육성 등 소방 교육훈련의 운영개선 및 체계혁신을 위해선 다음과 같다.

첫째, 공군 소방요원의 전문자격 인증 확대를 통한 소방직 무에서 요구되는 전문교육과 전문자격 취득 확대가 필요하 다. 인사 관리상 진급 가점 적용 방식을 개선하여 실질적인 화재현장에서 소방구조 - 화재진압 등 맞춤형 소방 교육 훈련 체계가 필요하며 전문자격(화재진화사, 인명구조사 등) 취득을 장려하는 방안을 모색되어야 한다.

둘째, 공군 교육부대의 소방 전문교관으로 자질과 능력을 겸비한 전문성을 갖춘 교관의 확보가 필요하다. 공군 내 경험과 지식이 풍부한 교관을 장기적 관점에서 육성 관리하 고 해외기관 간 협력 및 파트너 쉽을 통해 전문지식을 체계화 해 나갈 필요가 있다.

셋째, 교관 선발 시 직무와 관련된 다양한 경험자를 인센티 브 적용하여야 한다. 공군 교육부대의 소방교육과 연계한 교육-훈련에 적용 할 수 있도록 해외교육 및 훈련 이수자에 대한 교관 선발 시 인센티브를 적용하여 소방교육 대상자들 에게 간접체험 기회를 확대하고, 이는 군 소방 전문요원들의 선진 지식 전파 및 교육·연구를 장려할 수 있는 기대 효과를 가질 수 있다.

넷째, 재난현장에서의 의사결정의 능력을 향상시키기 위 한 교과목 개발 및 보수과정이 필요하다. 다양한 재난현장 및 화재 현장에서의 초동조치를 위한 소방팀원 간 의사소통 및 의사결정은 무엇보다 중요하다. 따라서 상황 판단력과 의사결정력 배양을 위해 의사결정능력을 향상시킬 수 있는 직급별 교육과정을 개발하여 화재 초동지휘관으로서 정확 한 의사결정을 할 수 있는 역량을 강화해야 한다.

다섯째, 실제 화재진압 훈련을 위한 위탁교육을 확대하 기 위해서 국 - 내외 관련 기관과의 소방훈련 양해각서 (Memorandum of Understanding, MOU)를 체결하여 민 · 군 공용공항의 실제 모의항공기 화재진압 교육 - 훈련을 실시 해야 한다.

이 외에도 한국 내 주둔한 미 공군 기지 실제 화재 훈련 시설을 활용하여 한·미 공동 교육·훈련을 활성화하는 등 실제 화재 합동훈련을 주기적으로 진행하여 화재진압과 인명 구조를 위한 초동조치 소방 능력을 강화할 수 있을 것으로 판단된다.

\section{References}

Cho, Y.C. (2013). An analysis of factors influencing response ability of firefighters at a disaster site. Master's thesis, Kyonggi University, pp. 27-30.

Department of the Air Force. (2017). Air force specialty 
code (AFSC) - Career field education and training plan for fire protection. Department of Defense (DoD) Fire Academy.

Im, J.H. (2006). Fire Education and Training Strategies for Newly-Appointed Fire officers. the Journal of National Fire Service Academy Vol. 4, pp. 25-41.

Lee, J.C. (2014). A study on the awareness of fire fighters in professional qualification. Master's thesis, Kangwon National University, pp. 2-10.

Lee, J.M. (2016). The Report on Fire Protection.

Ministry of Land, Infrastructure and Transport (MOLIT). (2013a). Airport operations standards (AOS) 20-21: Education and training. p. 4.

Ministry of Land, Infrastructure and Transport (MOLIT). (2013b). Standard 147: Rescue operations and education and training for fire employees. Airport Operations Standards (AOS), pp. 4-90.

Ryu, C.H. (2017). A study on the installation of fire facilities in aircraft hangars for military facilities. Master's thesis, Kyonggi University, pp. 6-11.

Seong, H.S. (2013). The study on the reinforcement of the incident commander's decision making abilities. Master's thesis, Kangwon National University, pp. $33-45$. 